\title{
Analysis on the teaching method of the teaching of Ideological and political theory courses in Colleges and Universities
}

\author{
Liying Yin \\ Jilin Agricultural University, Changchun 130118, China \\ ylyjlnd@126.com
}

Keywords: Ideological and political theory course, the problem teaching method, Implementation, way.

\begin{abstract}
The problem teaching method is to make the student problem consciousness and innovative thinking of a kind of teaching method. But in the implementation of ideological and political theory teaching in certain problems to be solved. Therefore, the implementation of teaching methods, the ideological and political theory teaching must be: design practical and creative ways of learning, focusing on independent and cooperative, paying attention to teaching process open and diverse, in order to improve the students to find problems, analyze problems, problem-solving ability. Therefore, the implementation of teaching methods, the ideological and political theory teaching must be: design practical and creative ways of learning, focusing on independent and cooperative, paying attention to teaching process open and diverse, in order to improve the students to find problems, analyze problems, problem-solving ability.
\end{abstract}

\section{Introduction}

Implementation of the teaching method of College Ideological and political theory course, to implement the "student oriented" concept of education, enabling students to better understand and internalize knowledge, improve the analysis of problems of college students, the ability to solve problems, improve the effectiveness of Ideological and political course teaching in Colleges and universities.

\section{What means the problem teaching method?}

\subsection{The meaning of the problem teaching method}

The problem teaching method is a kind of teaching method which makes the students have the problem consciousness and the innovative thinking. The teacher according to the student's cognition rule, according to the teaching content request, the teaching material knowledge question form in front of the student, guides the student Combined with their own life or have learned the theoretical knowledge found and asked questions, so that students in the thinking, discussion, problem-solving thinking activities, master the appropriate knowledge, the development of intelligence, training capacity, in particular, to develop students to identify problems and solve problems, reflect the problem, analyze the problem, solve the problem inherent Logical relationship, in terms of its nature, the problem of teaching method is a kind of human thinking and cognitive laws of the scientific teaching method, is the problem as the core, through teacher and student interaction and exchange to achieve teaching content and teaching Target teaching method.

\subsection{Characteristics of problem teaching method}

\subsubsection{Autonomy}

The implementation of the problem teaching method teaching is to give full play to students' initiative, initiative and creativity, the use of critical consciousness and innovative consciousness to find problems, analyze problems and solve problems, highlight the student's dominant position. Students are the active explorers and constructors of knowledge. Teachers are only the guides and assistants of student learning. Focus on the cultivation of students' self-learning ability, to promote 
students to develop a proactive exploration, try, independent access to relevant information to collect information, self-arranged learning process and self-improvement of self-learning habits.

\subsubsection{Openness}

Implementation of the teaching method of teaching, is to make students not only limited to the study of books, but extended to social life, better capture knowledge and more fully grasp the life, to provide students with understanding society, experience life and experience The First of all, the performance of learning objectives in the open, that is, the teaching process not only focus on knowledge learning, pay more attention to the ability to improve. Second, the performance of the learning process is open, that is, the teaching process to break the closed state, the full and effective use of school, outside the school learning resources, so that students get a rich learning experience. Once again, the openness of learning achievement evaluation is the diversification of the methods and ways of answering questions in the teaching process. As long as they meet the logic of the discipline and the psychological logic of the students, the same question allows different answers. Students can express different opinions.

\subsubsection{Cooperative}

Implementation of the teaching method of teaching, is to allow students to take a group discussion to learn, which is to develop students to learn autonomy in an effective way, that is, students find problems, the group discussion and analysis, to seek the best answer. In the discussion and analysis process, through the teachers and students, between the appropriate exchange of students, and actively publish personal views and views, sharing of learning experience and learning outcomes, both conducive to the improvement of learning efficiency, more conducive to student unity and Cooperative training

\section{An Analysis of the Problems in the Teaching of Teaching Law in the Implementation of the Ideological and Political Theory Course in Colleges and Universities}

The current ideological and political theory course in most universities is the large classes, students of different majors is often hundreds or even hundreds of people in a large class. This kind of class, the teacher could not be careful to understand the students, it is difficult to teach each other. Coupled with limited school hours, heavy teaching tasks, teaching content abstract, most students cannot be pre-class preview to do "know fairly well." In this case, it is difficult for teachers to communicate with students, and the teaching of Ideological and political theory course is inevitable.

\subsection{The problem design emphasizes on the teaching materials and the lack of correlation between subjects}

The problem teaching method must first design the problem, it is necessary to stimulate students to explore the desire of the problem, but also for the problems raised by the expansion and migration of knowledge. However, some teachers of Ideological and political theory course is not aware of the problem teaching method plays an important role in teaching, only to see the partial functions, the lack of a comprehensive understanding of its use is not deep enough, and more dependent on teaching material to design problems, mistakenly believe that the answers to these questions, we completed the task of teaching, achieve the teaching purpose and, the problem teaching method implemented in the whole process of teaching. But this way, making the problem boring, tedious, students only on the surface of the participation, the actual no brain thinking, but the formal problem of teaching, completely contrary to the essence of the problem teaching method, students learning interest is also slowly weakened. In the process of implementation problems of ideological and political theory teaching, student is the center and the main body, around students' life and learning practical design targeted problem, dare to touch time focus and social hot spot, thus achieve the purpose of their major.

Ideological and political theory course is a comprehensive discipline, involving philosophy, history, law, economics, psychology, sociology and other disciplines, which requires the implementation of teaching, theoretical teaching should be combined with the actual situation, to expand their horizons of knowledge. However, some ideological and political theory teachers in the design of the problem, answer questions when only focus on political knowledge, ignore the political problems and specific 
historical background and social reality, caused the students to analyze and solve problems of vision and vision is narrow.

\subsection{Too much interference in the teaching process, the main body of students is not established}

The traditional teaching mode and examination oriented education, the majority of the ideological and political theory class is lack of democratic atmosphere, teachers of Ideological and political theory course teaching is still stuck in the level of teaching theoretical knowledge, students are asked to ask, ask to ask, ask not ask, do not develop innovative, independent and explorative learning habits, lack of knowledge and understanding of life sublimation ability, students' enthusiasm to participate in the question teaching method is not high. The ideological and political theory course has a loose attitude, unintentional participation in classroom teaching teachers and students interaction, so that teachers in the implementation of the problem of teaching methods in the process of students can not actively cooperate with, greatly reducing the implementation of the problem teaching method, students' problem consciousness and Innovative thinking.

\subsection{The teacher pursues the standardization of the answer to the question, lacks the openness of the answer}

The teaching steps of problem teaching method in Ideological and political theory course is generally found the situation - question - discussion - conclusion, that the question analysis of the problem solving process. However, most of the teachers only focus on the final conclusion, given the standard answer. This method is simply as a means of teaching, teachers lack the understanding and awareness of students, lack of inspiration and placement of students, the lack of encouragement and recognition of students, the result is the students accepted the teacher's standard answer, the long run, students thinking rigid, also more and more small, gradually lost the enthusiasm of learning.

\section{Analysis on the teaching method of the teaching of Ideological and political theory courses in Colleges and Universities}

\subsection{Problem design should focus on practical and creative, improve the ability of students to find problems}

Comenius thought:" We should use all the way the children's desire for knowledge and desire to study it", ideological and political theory courses using problem teaching method should also pay attention to this point. To complete the construction of knowledge, access to the effectiveness of learning, students need to play the imagination, the problem analysis and exploration. This requires the teaching of Ideological and political theory in the process of implementation of teaching methods in the design problems in the premise of respecting the textbook, based on objective facts, meet the students' actual life and learning, through personal experience and investigation, the use of relevant knowledge, to further deepen the perception of the problem, the solution of the problem students can learn the theoretical knowledge, but also improve the ability of using knowledge.

At the same time, we should be creative when design the problem. Einstein said: "Interest is the best teacher." Students have the interest of learning will be pursued. Design the problem to seize the students' points of interest, you can design novel problems, so that students immersive, causing emotional resonance, and then stimulate the desire to explore and explore.

\subsection{The learning style should focus on the autonomy and cooperation, improve the ability of students to analyze the problem}

Independent learning is a necessary requirement student growth and success. In the ideological and political theory course teaching, students need to establish the main body awareness, clear their own is a party Teaching benefits teachers as well as students. equivalence, to play their own potential, influence of active learning and education, in-depth understanding and mastery of knowledge, and pay attention to reality, find problems to actively consult, discuss, and achieve the goal of learning; at the same time, teachers should give students the guidance, to give students sufficient time for students to carry on thorough analysis, to maximize the enthusiasm and initiative of students, cultivate their independent inquiry, consciousness and ability to solve problems. Teachers and students work together 
to explore and cooperate with each other to seek solutions to the problem, enhance their self-confidence and improve their ability of self-study.

Students' autonomous learning is not alone, but cooperative learning, with all the students' interaction and cooperation as the basic driving force, it aims to enhance the cooperation of students in the study activities, enhance the communication and information communication between each other's thoughts and feelings, strengthen the cooperation and competition consciousness in the students 'learning process, and comprehensively improve the students' innovation ability and interpersonal communication ability.

The implementation of the problem teaching method, whether it is the development of the plan, the collection of information, or the implementation of the steps, data processing, etc., need to rely on the overall efforts of the assembly team. There is a sense of independence and the spirit of cooperation in order to successfully complete the task and be optimized and improved.

\subsection{The teaching process should be open and diverse, to improve students' ability to solve problems}

If the problem is attractive, it must come from the social reality. This requires that the problem teaching method should promote openness, oppose the closure, and pay attention to the combination of classroom learning and social practice. In the teaching content, the requirements cannot be limited to the teaching materials, should be open to the moral and value areas of human beings, and to the development of social space, so that students from passive learning to actively take the initiative to explore. In the teaching methods, the decision of the diversification of student learning channels, the problem teaching should build a platform for students to understand themselves, show themselves, to achieve self. In the whole process of teaching, students use the existing experience and knowledge to learn and understand the new knowledge, and in their own lives and practice to prove that the final emotional, knowledge, skills, the unity of the three.

\section{Summary}

College ideological and political theory course is a compulsory course for college students to carry out ideological and political education, emphasizing the unity of knowledge, love and behavior, which requires effective teaching methods. The implementation of problem teaching method, combined with the ideological and practical, guide students to ask questions, analyze and solve problems, is college students to establish correct world outlook, outlook on life and values, to get the actual need of all-round development, is the effective method to improve the ideological and political theory teaching effectiveness, is more effective ways of cultivating socialist builders and successors.

\section{References}

[1]. Liying Yin Use of question teaching method in the teaching of ideological and political theory course in universities.

[2]. PROCEEDINGS OF THE 2ND INTERNATIONAL CONFERENCE ON MANAGEMENT SCIENCE AND INNOVATIVE EDUCATION(MSIE 2016), SANYA, CHINA, 15-16

[3]. Ping Xu Problem-based teaching method in the ideological and political theory course teaching the application of reach. MASTER, Hainan Normal University, CHINA 2013.p7-8. 